THE EVOLUTION OF GOVERNMENT HOUSING POLICY:

The Case of New South Wales 1901 - 1941

Patrick N. Troy

Urban Research Program

Working Paper No. 24

September 1990

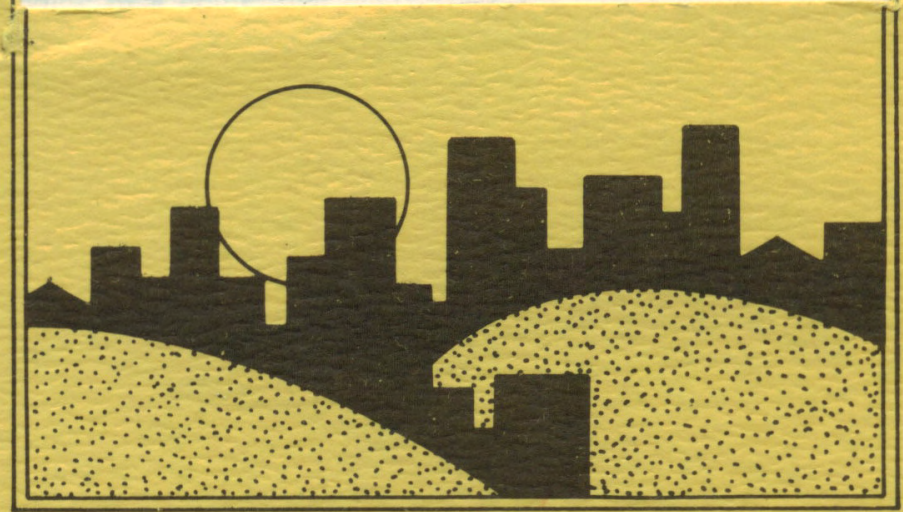

URBAN RESEARCH PROGRAM

ESEARCH SCHOOL OF SOCIAL SCIENCES

G

6 HT 101

AUSTRALIAN NATIONAL UNIVERSITY

. 877

no. 24 
THE EVOLUTION OF GOVERNMENT HOUSING POLICY:

The Case of New South Wales 1901 - 1941

Patrick N. Troy

Urban Research Program

Working Paper No. 24

September 1990

SERIES EDITOR:

R.C. Coles

ISBN $073151100 \mathrm{X}$

ISSN $\quad 1035-3828$

Urban Research Program Research School of Social Sciences Australian National University GPO Box 4 Canberra, ACT, Australia 2601 
(C) Urban Research Program, Research School of Social Sciences, Australian National University 1990

National Library of Australia

Cataloguing-in-Publication data:

Troy, Patrick Nicol, 1936-

The evolution of government housing policy.

Bibliography

ISBN $073151100 \mathrm{X}$.

1. Housing policy - New South Wales 2. New South Wales - Politics and government - $1901-1945$. I. Australian National University. Urban Research Program. II. Title. (Series : Urban Research Program working paper; no. 24).

354.994400865

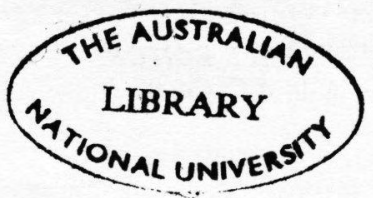




\section{URBAN RESEARCH PROGRAM WORKING PAPERS}

The Urban Research Program is a part of the reorganised Division of Economics and Politics in the Research School of Social Sciences which came into being in early 1990. Like its precursor, the Urban Research Unit which was established in 1966, it carries out studies in the social sciences on Australian cities. Work undertaken in the Program is multidisciplinary and ranges widely over economic, geographic, historical, sociological, and political aspects of urban and regional structure and development, as well as more general areas of public policy.

Working Papers are issued on an occasional basis with the intention of stimulating discussion and making research results quickly and easily available. Most papers will be published in final form elsewhere. In some cases, material will be published which, although of specialist interest, has no ready outlet.

Working Papers represent the work of members of the Program or papers presented to a URP-sponsored seminar or conference. In most cases, the Working Papers are Australian in content or relevant to the Australian context. Proposed papers are subject to a preliminary internal review of a committee comprising the-Series Editors and the Head of Program. If the review committee deems the papers suitable for possible publication, it is then sent to at least one external assessor for further comment.

The views expressed in these papers are those of the authors and not the Urban Research Program.

Series Editor:

Rita C. Coles 


\begin{abstract}
This paper reviews the development of four main threads of housing policy in New South Wales from the latter part of the nineteenth century through the first forty years of the twentieth century. Through a discussion of the social and political circumstances and debate surrounding government policy regarding landlord/tenant relations, housing quality and supply, and owner occupancy; it argues that policy evolution is irregular and a product of the exigencies of the political process. It also argues that although government policy did little to improve the housing situation for the underprivileged, there was nevertheless a growing acceptance by both Labor and conservative parties of the increased need for government intervention in the housing market.
\end{abstract}




\title{
THE EVOLUTION OF GOVERNMENT HOUSING POLICY: THE CASE OF NEW SOUTH WALES 1901 - 1941
}

\author{
Patrick N. Troy 1 \\ Urban Research Program
}

\section{Introduction}

During the nineteenth century, NSW governments became increasingly involved in housing policy. They first ventured into mediating landlord/tenant relations and then, following expressions of public concern, essayed initiatives in improving or protecting housing quality (Troy 1988). The century ended with major reforms of landlord/tenant relations.

This paper continues the story of the development of New South Wales Government housing policy into the first forty years of the twentieth century. It shows how the policy mediating landlord/tenant relations developed and how concern over housing quality found formal expression. The paper also discusses two new developments; namely the way NSW governments attempted to influence the supply of housing, and their interest in housing tenure. The four streams of policy are treated separately in this paper, but developments in them were usually inextricably interwoven. Moreover, the paper shows how policy evolution is irregular, and is a function of the exigencies of the political process.

The twentieth century began with new hope. On 1 January 1901 the various colonies federated to form the Commonwealth of Australia. NSW seemed to be recovering, if slowly, from the Depression of the 1890 's, the political turmoil of the 1880's and 1890's seemed to have passed (Loveday Martin and Parker 1977, Nairn 1973, Hawker 1971) and the State was experiencing a new political stability. The bureaucracy had been the subject of a Royal Commission, reformed and professionalised through the enactment of the Public Service Act 1895, and administration was consequently improved.

1 I wish to acknowledge the assistance of Shelley Schreiner and Rita Coles in the preparation of this paper. All misperceptions, misunderstandings, flights of fancy or common or garden errors are my own work. 


\section{Landlord/tenant relations}

From earliest settlement, landlords enjoyed a special legal prerogative in that any debt in the form of rent due them by a tenant took precedence over any other debts the tenant might have. The landlord had the right to distrain any property of the tenant in payment of the rent due without recourse to law. This power of the landlord was progressively modified to exclude the clothing the tenants wore, their bedding and, finally, their tools of trade. By the 1880's the power of landlords to distrain for rent was under challenge. Increasing use of the power in the Depression of the 1890's led to popular calls for its abolition. In 1890 an attempt to limit landlords' powers over the property of lodgers was defeated (NSWPD 1890:357), as were the 1893 (NSWPD 1893: 5557) and 1894 (NSWPD 1894:1952) attempts to abolish distress for rent, on the grounds that landlords should have no precedence over other creditors. Property interests prevailed in the Parliament. The pressures for reform however, were maintained and met with modest success when women tenants were finally given the same limited protection as men in having their 'sewing machines, mangles, and typewriters' recognised as tools of trade and protected from distraint (NSWPD 1898:325).

The nineteenth century ended with the passage in 1899 of a new Landlord and Tenant Act which consolidated in one Act all the reforms which had been introduced over the previous fifty years and, in particular, set out new procedures to govern evictions. The legislation retained the power of landlords to distrain for rent. From 1905 repeated attempts were made to limit or remove this power (NSWPD 1905:1269), but again the property lobby in the parliament was too strong.

Throughout the period 1901-41, house rents in Sydney remained at a high level, consuming up to an average thirty-five per cent of income (Bethune 1977). At times, house rents in Sydney increased at a rate considerably faster than wages (Table 1). The McGowen Labor government established a Select Committee on the Increase in House Rents which reported in 1912. It argued that the high rents were a consequence of a housing shortage caused by the low 
Table 1: Rental Costs 1911-1941: Sydney

\begin{tabular}{|c|c|c|c|}
\hline Year & $\begin{array}{c}\text { Annual Male } \\
\text { Earnings \$ }\end{array}$ & Annual Rent \$ & $\begin{array}{l}\text { Rent as \% } \\
\text { of Earnings }\end{array}$ \\
\hline 1911 & 245 & 71 & 28.98 \\
\hline 1912 & 268 & 77 & 28.73 \\
\hline 1913 & 273 & 82 & 30.04 \\
\hline 1914 & 271 & 84 & 31.00 \\
\hline 1915 & 279 & 86 & 30.82 \\
\hline 1916 & 306 & 87 & 28.43 \\
\hline 1917 & 315 & 88 & 27.94 \\
\hline 1918 & 326 & 92 & 28.22 \\
\hline 1919 & 379 & 96 & 25.33 \\
\hline 1920 & 459 & 108 & 23.53 \\
\hline 1921 & 434 & 111 & 25.58 \\
\hline 1922 & 419 & 109 & 26.01 \\
\hline 1923 & 447 & 122 & 27.29 \\
\hline 1924 & 423 & 128 & 30.26 \\
\hline 1925 & 444 & 131 & 29.50 \\
\hline 1926 & 480 & 128 & 26.67 \\
\hline 1927 & 493 & 127 & 25.76 \\
\hline 1928 & 475 & 131 & 27.58 \\
\hline 1929 & 476 & 133 & 27.94 \\
\hline 1930 & 402 & 137 & 34.08 \\
\hline 1931 & 335 & 118 & 35.22 \\
\hline 1932 & 296 & 102 & 34.46 \\
\hline 1933 & 302 & 99 & 32.78 \\
\hline 1934 & 324 & 99 & 30.56 \\
\hline 1935 & 345 & 102 & 29.57 \\
\hline 1936 & 378 & 106 & 28.04 \\
\hline 1937 & 426 & 113 & 26.53 \\
\hline 1938 & 445 & 118 & 26.52 \\
\hline 1939 & 447 & 122 & 27.29 \\
\hline 1940 & 461 & 122 & 26.46 \\
\hline 1941 & 520 & 122 & 23.46 \\
\hline
\end{tabular}

Source: G Bethune 1977, Urban Home-Ownership in Australia: Some Aspects of Housing Demand and Policy, PhD Thesis, Australian National University, Table 6.4, p. 247; and various Labour Reports.

Notes: Annual Male Earnings: average nominal weekly wage rate for Sydney weighted by the proportion of NSW trade-union members employed. Excludes overtime and over-award payments. Annual Rent: C series index of rents of 4 and 5 room houses. Extrapolated for 1911-1913 with A series index. 
Table 2a: Population 1881-1947, Sydney

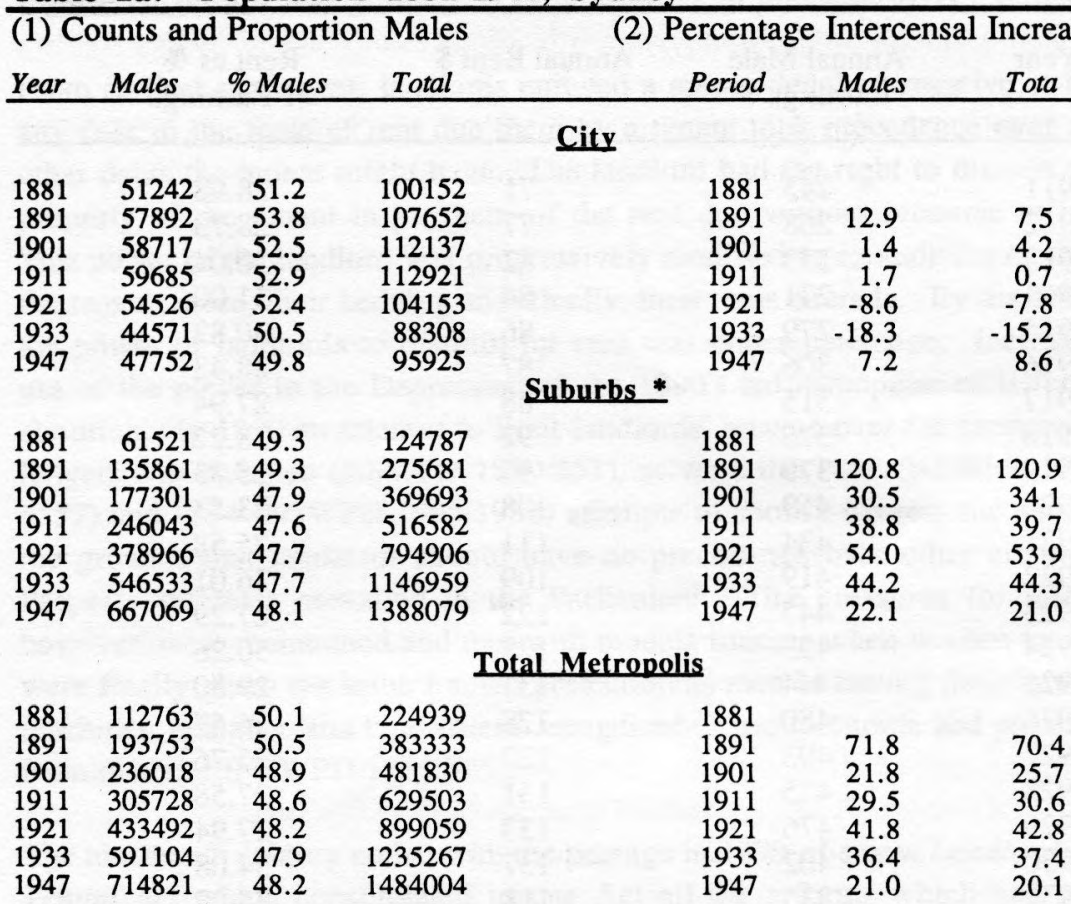

Table 2b: Population 1881-1947, NSW

(3) Counts and Proportion Males $\quad$ (4) Percentage Intercensal Increase

\begin{tabular}{rrrrrrr} 
Year & Males & \% Males & \multicolumn{1}{c}{ Total } & Period & Males & Total \\
\hline 1881 & 410211 & 54.7 & 749825 & 1881 & & \\
1891 & 609666 & 54.1 & 1127137 & 1891 & 48.6 & 50.3 \\
1901 & 710264 & 52.4 & 1355355 & 1901 & 16.5 & 20.2 \\
1911 & 857698 & 52.1 & 164674 & 1911 & 20.8 & 21.5 \\
1921 & 1071501 & 51.0 & 210371 & 1921 & 24.9 & 27.5 \\
1933 & 1318471 & 50.7 & 2600847 & 1933 & 23.1 & 23.8 \\
1947 & 1492211 & 50.0 & 2984838 & 1947 & 13.2 & 14.8 \\
\hline
\end{tabular}

Source: Tables 2a, b-NSW Statistical Register 1939-1940; 1942-1943; 1948-49

Notes: Figures for Sydney exclude Full-blood Aboriginals and shipping.

*The suburbs comprised 40 municipalities and Ku-ring-gai Shire in 1921 and 49 municipalities including Ku-ring-gai in 1933. For changes since 1891, in the municipalities comprising the Metropolis, see Tables 4 \&6 NSW Statistical Register 1942-43.

NSW figures exclude Full-blood Aboriginals. From 1911 when ACT was transferred to Commonwealth, ACT population is excluded. 
Table 3: Population and Dwellings 1891-1947, Sydney

\section{City}

\begin{tabular}{lccl}
\hline Year & $\begin{array}{c}\text { Occupied } \\
\text { Dwellings }\end{array}$ & Population & $\begin{array}{c}\text { Occupancy } \\
\text { Rate }\end{array}$ \\
\hline 1891 & 19145 & 114310 & 6 \\
1901 & 19799 & 120068 & 6.1 \\
1911 & 18463 & 112921 & 6.1 \\
1921 & 17391 & 104153 & 6 \\
1933 & 18692 & 88308 & 4.7 \\
1947 & 21863 & 95925 & 4.4
\end{tabular}

Suburbs

\begin{tabular}{lccc}
\hline Year & $\begin{array}{c}\text { Occupied } \\
\text { Dwellings }\end{array}$ & Population & $\begin{array}{c}\text { Occupancy } \\
\text { Rate }\end{array}$ \\
\hline & & & \\
1891 & 55466 & 293210 & 5.3 \\
1901 & 74863 & 396794 & 5.3 \\
1911 & 111487 & 554228 & 5 \\
1921 & 180718 & 867713 & 4.8 \\
1933 & 269548 & 1146959 & 4.3 \\
1947 & 358138 & 1388079 & 3.9
\end{tabular}

Total Metropolis

\begin{tabular}{lcccc}
\hline Year & $\begin{array}{c}\text { Occupied } \\
\text { Dwellings }\end{array}$ & Population & $\begin{array}{c}\text { Occupancy } \\
\text { Rate }\end{array}$ & $\begin{array}{c}\text { State } \\
\text { Proportion* }\end{array}$ \\
\hline 1891 & 74611 & 407520 & 5.5 & 36.2 \\
1901 & 94662 & 516862 & 5.5 & 38.1 \\
1911 & 129950 & 667149 & 5.1 & 40.5 \\
1921 & 198109 & 971866 & 4.9 & 46.3 \\
1933 & 288240 & 1235267 & 4.3 & 47.5 \\
1947 & 380001 & 1484004 & 3.9 & 49.7 \\
\hline
\end{tabular}

Source: $\quad$ NSW Statistical Register, 1942-1943,1948-1949.

Notes: Population counts above relate to Metropolitan Area as it existed at the date of the 1933 Census and therefore differ slightly from figures in Table 2

*Proportion of population of state residing in Metropolis 
level of construction during and since the Depression of the 1890's, demolitions in inner Sydney following the typhoid and cholera epidemics, slum clearance programs of the Sydney Corporation and were exacerbated by increased demand due to population growth. Landlords took advantage of the situation. The Committee suggested that steps be taken to regulate house rents.

In 1913 the government sought to implement a rent control system, part of its election platform aimed especially at its inner city constituents. The inner city areas had the lowest home ownership levels, and were thus most affected by landlords seeking to maximise their returns. The Legislative Council thwarted the government (Kass 1987). The situation continued to deteriorate and 'rackrenting' remained prevalent. Following the election of December 1913, in which rent control was a major issue, the Holman Labor government was able to claim that it had a mandate and enact the Fair Rents Act in 1915 under which Fair Rents Courts were to be established (in the event, only one court was established for the Sydney area). It was claimed that the Act simply had the effect of discouraging investment in rental housing. Evatt (1920) made the point that similar disinclination to invest existed in Melbourne and Brisbane which did not have such legislation. Evatt pointed out that in its first three years only forty per cent of cases brought before the Fair Rents Court resulted in a reduction in rents and that about fifteen per cent actually had a rent increase awarded. He concluded that there was a shortage of accommodation in Sydney, estimated at 9,000 dwellings in 1917 and 13,000 in 1919.

Pressure on the Commonwealth government to 'do something' about the housing situation in 1918 was hardly less than on the New South Wales government. Using its powers under the Interstate Commission, the Commonwealth conducted an investigation into prices. Mr. A.B. Piddington, Chief Inter-State Commissioner, took the evidence in Sydney during which hearings the desperate situation in that city was revealed and some witnesses argued that the Fair Rents Court was a major cause of increased rents because investors had been scared off. He expressed the view that any such effect could only have been secondary or supplemental because similar effects had been observed in Melbourne and Brisbane where there were no Fair Rents Courts (The Piddington Inquiry 1918).

The housing shortage continued to be reflected in rents and in 1920 the Fair Rents Act was amended to create offences for demanding key money or 
premiums for leases or renewals or for discrimination against households with children. Following the return of a Labor government in 1926, the Fair Rents Act was extended to cover shops let at up to $£ 6$ per week and the circumstances under which landlords could recover possession of a dwelling were tightened.

Notwithstanding the increasing powers of the Court, rents continued to rise. At the end of 1926, in his Declaration of the Living Wage for Adult Male Employees, A.B. Piddington, now the NSW Industrial Commissioner, expressed the view that 'the housing and environment of large numbers of the population is deplorable' (Piddington 1926:16). He nonetheless calculated that out of a weekly wage of $84 \mathrm{~s}$ a worker could be expected to pay $28 \mathrm{~s}$ rent.

The election of a conservative government in 1927, following a campaign in which rent control was a major issue, led to legislation in 1928 to emasculate the Fair Rents Court. It did this by restricting the coverage of the Act to dwelling houses built before 1928 and by ensuring that fair rent determinations applied for one year only. As a consequence of these amendments, the Act ceased to be effective and was removed from the statute book in 1937 (NSWPP 1961).

Dissatisfaction over rent levels and the power of landlords peaked during the Depression and the Labor government elected in 1930 abolished 'distress' which allowed landlords to confiscate tenants' property, something which had been on the Labor Party agenda for four decades (Landlord and Tenant Amendment (Distress Abolition) Act 1930).

Rents remained a contentious issue throughout the 1930 's, at times public discontent, especially among the lower income groups, being reflected in rent strikes. Although rents had been reduced at the height of the Depression, many felt that landlords increased them too rapidly in the recovery. By 1938 , the government was forced to try to gather information about rent levels and the rate of increase of rents for the lower end of the market. Mr. Justice De Baun of the Industrial Commission of New South Wales reported (NSWPP 1939) that there was a shortage of housing and that this was exacerbated by the building regulations and restrictions imposed by councils. He found that a small percentage of houses had rents which were too high, that most rents which had been increased in 1937 or 1938 were as high as they should be, and 
that some authority should have the power to set maximum rents for every dwelling.

Shortly after De Baun presented his report, war broke out and the Commonwealth and States agreed that rent control should be introduced for the duration of the war. The New South Wales government felt it should have its own legislation and enacted the Fair Rents Act of 1939 to cover dwelling houses. The same conservative parties which had seen nothing but disadvantage in the earlier rent control legislation reintroduced similar regulation of the housing market.

Critics of rent control policies always argue that they reduce incentive to invest in rental housing. At the margin they may have this effect but we observe that in Sydney the proportion of dwellings occupied by their owners remained steady at the three censuses, 1921, 1933 and 1947 (Table 4). This could have masked major changes in the inter-censal periods and we also observe that there was a large increase in the level of owner occupation between 1911 and 1921. It is clear from Tables 3 and 4, however, that there was a large increase in the number of dwellings built for rental in the period 1911-1921 (the dwelling stock increased by 68,159 but the number owner occupied increased by 38,433 , that is the rental stock, the overwhelming majority of which were private rental, increased by 29,726 ). In the period after 1921 the dwelling stock increased substantially, almost doubling by 1947 . Because the proportion owner occupied remained steady we can conclude that the greater part of the increase was rental stock, the overwhelming majority of which was for private rental. The prima facie evidence is that private investors were not discouraged by rent control legislation from investing in rental accommodation.

\section{Housing quality}

From the 1870 s the quality of working class housing emerged as a major area for investigation and debate. The reports of the Sydney City and Suburban Health Board in 1875-76 presented a disturbing picture of low income housing (Fisher 1981). Although the connection between housing standards and illness was well demonstrated, much of the tremendous growth of Sydney's population in the 1880 's, (Table $2 \mathrm{a}$ ), was accommodated in poor quality 
housing (Gerathy 1972, Fitzgerald 1987). Early in the 1880's, the Sydney City Council demolished some substandard housing, some of which was then replaced with new constructions, including dwellings, of a better standard. The effect of this was to reduce the supply of housing for low income households and to force them into the surrounding suburbs.

New South Wales governments in the nineteenth century often intervened in the provision of infrastructure, including roads, railways, schools and hospitals. A large number of laws and regulations affected the nature and quality of urban life, but governments were reluctant to regulate development of housing. This reluctance could have been a reaction on the part of influential politicians like Sir Henry Parkes to the degree of control exercised in England (Fitzgerald 1987), but Fisher (1982) suggests at least one alternative explanation lay in the power of the pastoral interests and their urban confrères to impede regulation of the noxious trades.

Local government authorities were under pressure to ensure that all buildings, but especially dwellings, were built to the highest standards. Most of them introduced or gazetted regulations and by-laws to regulate building standards. These regulations were meant to indicate minimum standards but were poorly enforced and were quickly accepted as the norm. The early concerns over building standards had focused on issues of structural integrity, observance of property boundaries and fire. Later the focus shifted to health issues.

The first 'health-based' regulations in New South Wales related to the provision of wholesome water supplies, sewerage and drainage. But the widespread adherence to the miasmatic theory of disease transmission led to a preoccupation with building ventilation. (Housing design remains significantly influenced by this consideration long after the abandonment of miasmatic theory.) The City of Sydney Improvement Act of 1879 was the first legislation to make provision for all rooms other than store-rooms or bathrooms, in dwellings, to be ventilated to the external air, to require windows to open to the external air and to set minimum ceiling heights ( 7 feet 6 inches).

With its Public Health Act of 1896, New South Wales was the last colony to introduce health regulations affecting the quality of housing. The Act made provision under the model by-laws for common lodging houses, that each 
sleeping room provide not less than $\mathbf{5 0 0}$ cubic feet of air space for each adult, that it must have a window capable of being opened to the external air and that it have an open fireplace or a ventilator or ventilators of 24 square inches open passage for each person. The Act also required the lodging house keeper to open the window for at least two hours each day and to air the bedding (note that keepers were not required to provide clean bedding - only to ensure that it was aired daily for at least an hour). Similar provisions were included in the Shearers' Accommodation Act of 1901 which required pastoralists to provide at least 240 cubic feet of accommodation for each man. The general concern over proper ventilation of space was also extended to cover working space (Factories and Shops Act 1896). Observation of the ventilation regulations resulted in housing which in winter was bracing if not healthy, leaving many an Australian family toasted on their faces and hands as they sat around the fire in the 'living room' but freezing on their backside and as soon as they retired to their bedrooms.

Although there is general agreement among historians (Jackson 1977, Glynn 1970 ,) that the average standard of living, including housing, was relatively high compared with Europe, Fitzgerald (1987) points out that significant numbers lived in poverty and the quality of their housing and their security of tenure, especially those in the centre of Sydney, aroused considerable concern. Markey (1988:4) claims that 'Working and living conditions for workers in the 1880 s rarely matched the expectations of prosperity, which were fuelled by the great boom from the 1850 s to 1891.' Sydney had a significant number of homeless men throughout the 1890's (in a debate in the House of Assembly in November 1893 it was claimed that 'there were more than 900 men found sleeping without accommodation' (NSWPD 1893:1087)) and by the turn of the century there were an estimated 1,000 homeless in the City.

Social and political pressure to protect and improve housing quality took on a new urgency with the cholera and bubonic epidemics experienced in Sydney in 1900 and 1901. Many houses in the 'Rocks' area of Sydney were demolished and their replacements were built to higher standards, with a large area resumed by the government to enable it to reorganise and rebuild for the wharves and warehouses and to provide housing for maritime workers. For the first twenty years of the century the clearance programs led to a substantial reduction in the number of dwellings in the City of Sydney (Table 3). Population fell in line with this reduction so the occupancy rate stayed much 
the same, as did the masculinity of the population, although the masculinity of the State's population was falling rapidly by the second decade (Table 2). The number of dwellings in the City of Sydney increased in the second half of the study period, as they did for the metropolis. Although the population increased, the number of dwellings increased at a faster rate and consequently the occupancy rate fell, indicating a significant easing in the degree of overcrowding in both the City and the metropolis as a whole.

Until 1934, regulations to control housing quality were not uniform. The regulations controlling the City of Sydney came under the City of Sydney Improvement Act of 1879 as amended. In the rest of the metropolitan area, and indeed the State, such regulations as were applied came under a variety of statutes. The epidemics of 1900 and 1901 led to amendments to the Sydney Corporation Act, the Public Health Act and the Local Government Act. The regulation of buildings under the Local Government Act of 1906 (Ordinance 70) became the vehicle for establishing housing standards everywhere except the City of Sydney. The regulations gazetted in 1913, for example, set a minimum floor area for rooms of 100 square feet; a minimum ceiling height for rooms other than attics, of ten feet; a minimum distance from windows to the allotment boundary, of three feet; at least one openable window in each room; adequate internal and under-floor ventilation; and specified dampcoursing, etc. (NSW Government Gazette 1913 No. 132). The Local Government Act was substantially revised in 1919, providing the framework for the progressive introduction of building standards and, ultimately, of town planning.

The current concern over consolidation and multi-unit housing has a long history. The protagonists in the controversy represent similar groups and advance similar arguments to those of sixty years ago. Then, as now, local authorities opposed the construction of flats or at the very least sought to establish high space and ventilation standards to control them, and argued the loss of amenity and safety. Builders' and developers' journals emphasised what we now call the infrastructure savings and the economy with which flats could be built, claiming that these in turn would result in cheaper housing. They argued that women preferred 'to live in a labor-saving and communal flat.' (Housing Section 1926:46), denied the dangers of low standard development and claimed there were no real slums in Australian cities. 
This assertion was surprising because poor quality housing and 'slums' had been drawn to attention by many commentators and reformers from the mid nineteenth century (Mayne 1980, Spearritt 1973, Spearritt 1974). Early in the twentieth century, J.D. Fitzgerald (1909) repeating well rehearsed arguments (NSWPD 1893:1122), pointed to the moral dangers of slums and argued for their removal. He contended that slums were the product of poor building regulations or the lax application of them. Protestant reformers also took up the issue of the slums (Boyce 1908) and claimed some success in encouraging the City of Sydney to clear slums in Chippendale (Boyce 1934). (The Church of England published a pamphlet entitled 'What the Church of England Has Done for New South Wales (c.1912) which set out its 'achievements' in housing reform. Throughout the early part of the century, a parade of reformers and commentators maintained pressure on the government for the removal of slum housing and the construction of decent housing at low cost.

Industry spokesmen denied the problem but the Legislative Assembly established a Select Committee on the Slum and Congested Areas, Sydney and Newcastle in 1920. The Sydney City Chief Sanitary Inspector expressed the view that there were no real slums in the City but some housing was overcrowded and below standard. He also argued that attempts to raise the standards would simply speed up the process of demolition of the dwellings which would then be replaced by factories and stores. In fact, thousands of terrace houses were demolished in Sydney's inner southern and western suburbs in the twenties and thirties for factory, warehousing or retailing purposes.

The slum clearance movement in NSW began to take shape in the 1930's and the formation of the Parks and Playgrounds Association in 1930 gave it additional thrust. Slum clearance pressures were significant in the founding of the Town and Country Planning Institute in 1934 and various professionals including leading architects entered the fray (Anderson 1935). The government responded to this pressure by creating the Provisional Committee for Slum Clearance under the Chairmanship of N.H. Dick who pointed to the connection between housing and the 'moral and physical condition of the people'. He also averred that Sydney's slums were the result of 'uncontrolled development' and proposed a statutory authority to clear them (Dick 1935). This pressure led to the passage in 1936 of the Housing Improvement Act . 


\section{Housing quantity}

During the last few years of the nineteenth century, spasmodic attempts were made to resolve the problem of low-income urban households by giving them a 'start'. With a mixture of philanthropy and ideology, civic leaders assumed that if only low-income households could be encouraged to make a commitment, they might become secure and develop their self respect and independence. The problem had a special prominence in the Depression of the 1890 's. In the political turbulence of the decade, few governments were in office long enough, had sufficient authority or were sufficiently committed to interventionist policies to attempt directly to influence the supply of housing. However, in 1893 the Dibbs Government proposed to solve the problem of homelessness and unemployment by establishing village settlements (Labour Settlements Act 1893) in which urban labourers would be resettled. Men were to be given access to land, loans for improvements and rights to purchase the property, and were required to work for the settlement for eight hours a day. Three settlements, Pitt Town, Bega and Wilberforce, were established on inferior land but they were not well administered and the men chosen were all 'practically destitute and few were used to labour on the land' (Coghlan 1969:1964). Pitt Town failed and was abandoned within a couple of years. Wilberforce and Bega struggled on but never developed in the manner originally envisaged.

The government successfully evaded pressure late in 1893 to provide land and building materials to enable the unemployed to build their own shelter. In 1934, however, a similar scheme was introduced under the Housing of the Unemployed Act. Although some commentators claim that Australia was an innovator in the field of social policy (Castles 1985), this did not hold for initiatives in the public provision of housing for low income households. New South Wales lagged behind Britain, where by the end of the nineteenth century, significant numbers of dwellings were being built for working class households (Pooley 1989).

The first 'urban' solution to the housing shortage and homelessness was the initiative in 1901 of the Blockholders Act. Under this legislation, working men could secure a 99 year lease on a block of Crown land of half an acre to 10 acres in the vicinity of Sydney and other population centres. They were also able to borrow up to $£ 50$ or not more than half the cost of any permanent 
buildings. The blockholder was required to live on the property. The land affected was generally of inferior quality, poorly located and, according to one observer, was 'infested with five corners and snakes' (NSWPD 1901). The first lands subdivided were at Lilyville, La Perouse (on Botany Bay), then an outer Sydney suburb, and the scheme never made more than a token contribution to the supply of housing. The subdivision was derisively known as 'Cricksville' after its architect, the Secretary for Lands, the Hon. W.P. Crick.

The same year (1901), an attempt was made to give the Municipal Council of Sydney the power to 'make provision for the better housing of the Working Classes in the City of Sydney'. The bill did not survive although it had the support of the City Council who actively campaigned for it. Housing conditions of the working classes continued to excite concern, although a 1904 initiative to make provision for the better housing of the poorer classes fizzled out. In 1905, the Sydney Corporation Act was amended to give the City Council the power to purchase or resume land, to provide for workmen's dwellings on the sites resumed or elsewhere, and to borrow the necessary moneys to enable it to do so.

The Labor government elected in 1910 responded to the acute housing shortage in three ways. The first, discussed above, related to rent control; the second was by the creation of a three-member Housing Board under the Chairmanship of J.D. Fitzgerald, operating under the Housing Act 1912; and finally by empowering the Sydney Corporation to build dwellings for its population (Sydney Corporation (Dwelling Houses) Act 1912). These initiatives were in response to the shortage of small houses for workers and growing concern over the increase in the area of slum housing. The major activity of the Board was the development of Dacey Garden Suburb (named after J.R. Dacey, Treasurer and the man responsible for the passage of the Housing Act. The originator of the idea was Dacey's predecessor as Treasurer, Campbell Carmichael.). The suburb was planned according to English Garden suburb principles by the architects J. Sulman and J.F. Hennessy.

The original plan for Dacey Garden Suburb was for 1,437 rental houses with provision made for parks, schools, public buildings and shops. Work on the scheme commenced energetically enough and in its first year 67 cottages were 
completed. But by the time the Board was abolished in 1924, only 309 dwellings, a public hall and eight shops had been erected on the estate.

Fitzgerald, a trade unionist who left the Labor Party over the conscription issue in the first World War, became Minister of Public Health in the Holman Nationalist government. He continued his interest in housing and planning, proposing to the Premier, W. A. Holman, that the Housing Board undertake housing programs in various locations. In 1918 he revived a Labor government initiative for a workmen's village in Stockton, a suburb of Newcastle, justifying it on the grounds that such a village would give the government relief from strikes because the better surroundings would give more 'contentment' for 'the women, children and men' and 'families are reluctant to leave their homes under such conditions, or risk being driven out' (At an earlier stage in his career he had travelled to England seeking financial support for strikers (O'Flanagan 1988)) Lack of funds meant that the proposal was not taken up (NSW Archives PDP B18/3273).

By late 1918, however, the government, under Fitzgerald's initiative and in collaboration with the Master Builders' Association, announced a scheme to build houses, on government-owned land, for sale to workers. The estates were to be planned to include industry, commerce, open space, public uses as well as residential sites. House sales were to be financed through the Government Savings Bank of New South Wales. Estates were developed at a number of sites including Stockton, and Matraville and Flemington in Sydney. The Matraville site was to be developed with housing for disabled servicemen and the widows of servicemen. The estate design was carried out by Sir John Sulman, without fee, and much of the construction was by volunteer labour (Watson 1921). The scheme as a whole received a mixed review by Wilkinson (1921), Professor of Architecture at the University of Sydney, who thought it an architectural and civic design opportunity lost.

The Board's activities elsewhere - especially those following amendment to the Housing Act in 1919 which extended its sphere of operations allowing it to build houses for sale and engage in land subdivision for sale - led it to erect a total of 818 dwellings and it made advances on a further 516 properties. It sponsored construction and subdivision projects in a large number of Sydney suburbs and country towns and by 1923 it also managed ten hotels - mostly in the 'Rocks' area. 
The Board suffered from frequent changes in the Ministry, lack of funds (brought about in part by the war effort and partly because the NationalistProgressive government of 1922-1925 did not favour public intervention in the market in the way that Labor or Nationalist administrations had from 1912), shortages of materials and inflation in prices, and ill-founded criticism. It was criticised for running rental housing at a loss, which was unfair as it was required to rent at cost and no provision was made for non payment of rents. The Board's defence was that in the long run, its housing operations as a whole would not sustain losses. The critical attitudes were similar to those expressed fifty years later by opponents of public housing programs. Some part of its difficulties, paradoxically, flowed from its apparent early success and the high expectations which led to the government imposing on it responsibility for administering the 'Rocks' or Observatory Hill area which had been resumed in 1900 following the outbreak of bubonic plague. These responsibilities, for which it received inadequate funding, were discharged creditably.

The extended operations following the 1919 amendments were not accompanied by appropriate administrative changes or increases in administrative resources. The Minister for Housing had no direct control over the Board which was the administrative responsibility of the Treasury which had little interest in any aspect of housing. The small organisation was severely taxed. This led to major management problems which were reflected in disputes with its clients and poor project supervision, creating controversy and allowing its critics a 'free shot'. The Board went down fighting. It sought opportunities to answer its critics and recommended remedial action. Its requests fell on deaf Ministerial ears and it was asked to resign (NSW Archives 7/5947), but rejected the request.

The Board's life was ended by legislation with it recording its dissatisfaction with its Minister and his communication with it (Annual Reports of the Housing Board 1913-1924). To justify its actions and to identify scapegoats (and possibly to punish those it felt were guilty of insubordination) the Government, in July 1924, vindictively charged three senior officers of the Board with 'gross mismanagement, carelessness, incompetence and improper conduct'. By May Day 1925 having subjected the officers to a Select Committee of the Legislative Assembly and an inquiry by the Public Service Board which found the charge 'not to be proved' the Premier decided to take 
no further action. The officers were not found guilty but the direct provision of housing by Government was damned - at least for the time being.

Responsibility for the mortgages for the houses which the Board had sold was transferred to the Government Savings Bank (Griffiths 1930). Dacey Gardens Suburb continued as a rental estate only partly completed until the 1930 's when the undeveloped blocks were sold off. Following the abolition of the Housing Board, the rental properties were reluctantly administered by the Public Trustee which tried several times to sell off the properties (but were prevented by the legislation) or to rid itself of the delegated responsibility. The Public Trustee was criticised by the Department of Local Government for failure to administer the estate and in 1934 the Minister for Local Government sought and received the support of his Cabinet colleagues to direct the Public Trustee to carry out its responsibilities for the estate. The Public Trustee again tried to rid itself of the responsibility for the estate in 1939, eventually succeeding early in 1940, when they were transferred to the Resumed Properties Department where they remained until they were handed over to the Housing Commission of New South Wales on its creation in 1941 (NSW Attorney General NSW Archives 5/7791.3). The area was allowed to run down despite repeated protests of the residents and the local member. The 'resumed properties' in the 'Rocks' area were handed to the Treasurer for administration and the administration of those properties which had been sold was transferred to the State Savings Bank.

The third way in which the 1910 Labor government responded to increasing concern over the quality and supply of housing was to commission Professor. R.F. Irvine in August 1912 'to enquire into the question of the housing of workmen in Great Britain and the Continent of Europe and America and to recommend for adoption whatever measures might with advantage be introduced into the State of New South Wales'. Irvine's 'Report of the Commission of Inquiry into the question of the Housing of Workmen in Europe and America' was published in 1913. Irvine travelled to Europe and America, visited housing projects and undertook research into a wide range of housing schemes.

Irvine developed a holistic view of housing best illustrated in the way he defined the 'Housing Problem' as being concerned with two questions: 
'(1) How, in the congested areas of large cities and in certain industrial centres, to get rid of the results of unregulated housing - over-housing, overcrowding, high rentals for inferior accommodation, and all the evils that flow from them.

(2) How society may best provide that each individual family unit, whether living in the city or country, may have a home that shall be self-contained, private, sanitary,open in every room to sunlight and fresh air, safe from fire and collapse, and yet at a rent consistent with income - a home that shall be artistic and hygienic, a home environment which shall be if not actually constructive, at least not destructive, of either body or character, and at a rent no higher than is paid for the slum tenements of to-day.' (Irvine 1913:1-2)

He also subscribed to the view widely held among housing reformers that housing was inseparably linked to town planning. His report endorsed the Dacey Garden Suburb initiative and went on to argue the case for improved town planning as the essential way of improving housing. Although he made powerful arguments in favour of intervention by the state in the market, he was strongly opposed to the State government itself becoming a house builder, and favoured municipal initiative in this area. His controversial report was overtaken by events but in 1914 he restated his major thesis in a pamphlet for the Town Planning Association of which he was a founding member and the then current Vice-President (Irvine 1914). The need for town planning and the connection between planning and improved housing was a theme repeated by Fitzgerald (1918).

The Depression of the thirties brought into high relief the housing problem, especially for low wage earners and for the unemployed. Following the abolition of the Housing Board in 1924, some attempts had been made by Labor governments to reduce rents and to modify the landlord/tenant relations, but little effort was made to increase supply.

The situation had deteriorated and the political pressures became so intolerable that the conservative UAP-Country Party government was forced to take steps to increase the supply of housing for the unemployed. It did this by creating a Homes for Unemployed Trust under the Housing of the Unemployed Act in June of 1934 . 
This Trust gave about 1,800 unemployed persons the materials, on a repayable basis, to build their own dwellings. It also built about 800 minimal standard, cheap, even cheapskate, houses in various locations in NSW. Partly because of this the Trust had poor relations with infrastructure authorities and with local governments, which opposed its operations. Regarded as ineffectual, the Trust made little contribution to the solution of the housing problem of the unemployed. Its Act was repealed in 1937. The assets and residual responsibilities of the Trust were transferred to the NSW Housing Commission when it was created under the 1941 Housing Act.

The housing situation was acute nationally, but nowhere was it more distressed than Sydney. Although it had hitherto been a State matter, it was an issue of such political saliency that during the September 1934 Federal election campaign, in Sydney, the Prime Minister, Joseph Lyons, promised a national housing program. The UAP-Country Party coalition was forced to intervene in the housing market again in 1936 by vocal concern over slum conditions (Bland 1938) including argument such as that of the Director General of Public Health (NSWPP 1936) who in his report for 1935 addressed a wide range of housing and town planning issues. It established a Housing Conditions Investigations Committee which presented an interim report in September 1936 . The Committee concluded that the housing conditions necessitated 'urgent consideration by the government'. In its report which argued that 'Private enterprise cannot afford to provide, within the means of the lower income group, the standard of accommodation necessary for decent living.' the Committee made a major shift in position for a conservative political party (NSWPP 1936:2). The extent of this shift was revealed when it stated :

'The first conclusion...is that the housing problem is inseparably bound up with town and country planning and that until adequate powers are given in the form of a Town and Country Planning Act the ideal solution of many of the major aspects of the housing problem cannot be attempted.

Secondly, while many aspects of the problem could be solved by the introduction of such an Act it would still be necessary to place a separate Housing Act on the Statute Book to deal with the detail of housing administration including its financial incidence. Such an Act would require the appointment of a statutory authority for administrative purposes.'

(NSWPP 1936:3) 
The government accepted the advice and speedily created the Housing Improvement Board of New South Wales under the Housing Improvement Act 1936. The Act had two main purposes: the first was to encourage home ownership (a topic we return to later), and the second was to encourage local councils to eliminate unsatisfactory conditions such as slums and provide housing accommodation.

Premier Sir Bertram. S.B. Stevens reported in 1937 to the Legislative Assembly on a study tour he made on 'Housing, Slum Clearance and the Abatement of Overcrowding in England' (NSWPP 1938 Vol. 5). His tour of England and other European countries convinced him of the need for a housing authority and town planning legislation. Stevens confirmed the new interventionist position of the conservative parties by arguing that governments had to accept the 'direct responsibility' for the housing of the small minority who lived in distress or insecurity (NSWPD Vol. 153: 2393). This opened the way for the government to return to the field of direct supply of housing.

In pursuit of its second objective, the major initiative of the Housing Improvement Board was the Erskineville Housing Scheme. Under this proposal, the Board proposed to construct a large block of flats in an area identified by the Housing Conditions Investigations Committee as being ripe for slum clearance. The Board proposed to build 222 flats (Briggs 1972). The Scheme was intended as a demonstration model to be followed by private entrepreneurs and local governments throughout the metropolitan area of Sydney. The proposal stimulated a major controversy.

Under its legislation, the Board was required to identify areas of congestion and overcrowding and to consult with local authorities on the best way of solving the problem. If the council agreed to its proposed solution, the Board could then seek the Governor's approval to the gazettal of a Housing Improvement Scheme. Erskineville opposed the proposal, ultimately forcing the government to seek wider powers under the Housing (Further Provisions) Act of 1937 enabling the Board to construct 56 flats. The Health Department was also given greater powers, empowering it to declare dwellings unfit for human habitation. 
The scheme had proponents like the noted architectural historian Morton Herman (1939), but it met with vociferous opposition from the local residents. Herman acknowledged that flats had a 'bad name' but no amount of rationalisation or appeals to European precedents would appease the opponents (Volke c.1980). No one disputed the need to improve housing conditions and there was widespread agreement that Erskineville housing was deplorable. What was in dispute was the form the new housing should take.

\section{Flats}

Flats had not been a popular form of housing in Australia. As early as 1919 planning reformers had inveighed against them as appropriate forms of housing for Australia (Howard 1919). One of the many petitions received by the government and the Board in August 1937 summed up the popular views toward them:

'(1) FLATS are not desirable. Where they have been undertaken on Communal lines in New South Wales they have invariably been a failure as instanced by the efforts of the Sydney Council (City).

(2) FLATS are unsuitable in an industrial area because the industrial classes have the largest families and large families and family homelife has been the backbone of the British Empire.

(3) FLATS on moral and religious grounds have a definite tendency to make people limit their families by birth control methods, which has a definite injurious effect on the health and morals of married peoples.

(4) Community grounds for drying clothes on washing days takes away the homelife which families have been used to and is foreign to industrial classes who have always had their own drying grounds. The washing and drying of women's private garments (personal hygiene, etc.,) demands the amount of privacy every female is entitled to.

(5) Private space for gardens and lawn tend to increase the homelife of the individual suppling for him a hobby that is so essential. This also allows children to 
play in their own backyards where they are under direct control of the parents. The appalling number of street accidents to children speaks for itself.

(6) If we desire to populate Australia with Australians we must encourage them to propagate. If people are encouraged to live in FLATS small families will result.

(7) The swampy area intended for building will make it necessary to have an up-todate drainage system instituted. In England it is illegal to build on made soil.

(8) Infectious cases in children must be isolated. How are we to isolate in COMMUNITY backyards?' (emphasis in original).'

Popular anxieties were not allayed by the agreements between the Board and its tenants, which appeared to place a lot of restrictions on the tenants.

Councils were well aware of popular views. They knew, moreover, that regardless of the advantages and benefits that the government claimed that well-designed, sensitively-located flats would bring, that the actual developments for the most part, in most locations, resulted in poor housing in poor environments. Councils' steadfast opposition was similar to, and for similar reasons to, their current opposition to 'consolidation'.

In an attempt to increase confidence in flats and to eliminate the more obvious malpractices which had grown up with their speculative construction, in mid 1940 the government introduced a Local Government (Regulation of Flats) Bill to regulate them. The Bill applied to the Metropolitan area other than the Sydney City Council area. Although amended, it became 'Schedule 7' of the Local Government (Regulation of Flats) Act in 1940. The new standards were designed to ensure adequate light, air, open space, prevent overshadowing and preserve amenity and they had the effect of virtually making it impossible to build blocks of flats more than three storeys high on suburban blocks.

The much hoped for demonstration effect from the Erskineville Scheme did not result in a stream of councils trying to repeat the experience and clearing their areas of slums. Neither was the private sector moved to emulate the exercise. The government was disappointed, but before it could reconsider its approach it was overtaken by war and overthrown in an election. The new 
McKell Labor government transferred administration of the estate to the newly formed Housing Commission in 1941

\section{Housing tenure}

Periodically over the past century, politicians have sought to ameliorate the results of the market economy by trying to find a way of guaranteeing people their accommodation by giving them security of tenure. We have seen above how tenants' rights were progressively secured. But late in the nineteenth century concern was expressed over the security of home owners. In 1890 the Legislative Assembly granted leave to introduce a Bill for an Act to vest 'in the individual citizens of the state an inherent right to a certain proportion of their property necessary for the decencies of home life and so forth, and against which no creditor could prevail'(NSWPD 1890:166). Although it was clearly aimed at rural settlers and was modeled on American experience the proposal applied to and was popular with urban home owners. The Bill was analogous to the initiatives introduced to limit the landlords' ability to distrain for rent arrears. It was lost in the political chaos of the period. Another attempt was made in 1896 to give protection to any home in NSW not exceeding $£ 200$ against alienation or seizure. Appeals to a sense of obligation to pass laws to protect women and children from acts of folly by their husbands or fathers were unsuccessful and the Bill failed (NSWPD 1896:3559).

In 1906 the Post Office Savings Bank of NSW, which had been established in 1871, formally became the Government Savings Bank of NSW (In 1914 it absorbed the Savings Bank of NSW which had been created in 1832). The Bank's Act was amended in 1913 to allow it to provide housing loans up to 75 percent of the house value, in an attempt to promote home ownership. This followed the introduction in Victoria of the 'Credit Foncier' system enabling borrowers to buy homes on easy terms in 1910. The system was popular and by 1929 the Bank held 22,254 mortgages at an average of $£ 514$ (Griffiths1930). The new loan facility was a major reason for the rapid increase in owner occupancy to the plateau reached by 1921(Table 4). This initiative in encouraging owner occupancy was similar to that found by Daunton (1988) in America compared with the direct provision of public housing in Britain. 
The first official concern over the extent of owner occupancy was revealed in 1911 when, for the first time, housing ownership was included in the national census.

\section{Table 4: Percentage of Houses Occupied by Owner in Sydney \&} NSW

\begin{tabular}{lcc}
\hline Year & Sydney & NSW \\
\hline 1891 & 27.8 & - \\
1901 & - & - \\
1911 & 31.1 & 44.0 \\
1921 & 39.8 & 46.9 \\
1933 & 40.5 & 47.2 \\
194 & 39.7 & 48.1 \\
\hline
\end{tabular}

Source: J.C Docherty (1982) Selected Social Statistics of New South Wales: 1961-1976, Sydney, History Project Incorporated University of New South Wales, p 32-34; T. Kass, (1987), 'Cheaper than Rent' in M. Kelly (ed), Sydney: City of Suburbs, Kensington, NSW University Press, p.78.

One of the proposals of the housing and town planning reformers of the second decade was to give tenants some equity in their housing. Both Sulman (1914) and Irvine (1913) promoted the notion of 'co-partnership' housing. There were some differences in the degree of cooperative or communal living in the elements of the various proposals. None were built.

By 1921, about half the dwellings in Australia and slightly less in NSW were owner occupied. Sydney had about forty per cent owner occupancy with the level even lower in the inner suburbs. The Bruce Commonwealth government introduced a scheme to increase the level of home ownership so that 'the half of the population which does not now own its own home being enlisted on the side of the other half which does, and there will therefore be a greater proportion of people with something at stake in the country with which to fight Bolshevism and other revolutionary forces, whose aim is to overthrow personal rights and property and banish individual effort and thrift.' ('Australians as Home Owners' 1926:52). The philosophy embodied in this proposal was directly related to the arguments used earlier by Fitzgerald and was to be repeated by Stevens in 1938 and again by conservative political 
leaders a decade later. Bruce's scheme was used by proponents, like the anonymous author quoted in the article in the journal Building above, to pressure the New South Wales government into taking similar initiatives.

Home ownership was seen as the ultimate way to stimulate an interest in civic affairs and national pride. Griffiths (1930:66) repeats a widely held view: 'Give a man something to lose and you give him something to fight for.' A decade later church leaders were able to expand this sentiment: 'When a man owns a home he has a stake in the country. He is of more value socially and politically and he is a better man morally and physically.'(Hammond, SMH 20:2:1939). Quite how these transformations would be effected was never made clear. (Nor was it made clear how those who did not own a house but who joined the armed forces could be expected to perform in battle or how they should be regarded.) The argument indicated a reductionist view of society and the sense of community and was ultimately codified in legislation. People did not have the right to vote in local elections under the Local Government Act of 1919 , unless they were 21 years of age, and were either an owner, ratepaying lessee or occupier of ratable land in the area. From 1880 to 1893 ownership of a freehold or leasehold estate in an area, qualified male British subjects over twenty-one to vote in Legislative Assembly elections (Electoral Act of 1880). Property based voting rights were eliminated for the Legislative Assembly in 1893 (Parliamentary Electorates and Elections Act of 1893). However, the retention of the property based franchise for local government elections meant that full citizenship was accorded only to those who were men of property. This tended to give weight to the notion of a property owning democracy.

\section{Comment}

This review of housing policy initiatives and legislation in New South Wales suggests that government actions were not sufficient to solve the housing problem. The period of the study started in 1901 with a housing shortage and with the widely held view that much of the stock was of poor quality. It ended in 1941 with an even greater shortage and, in spite of the clearance campaigns, even greater numbers of substandard dwellings. The initiatives taken to increase levels of home ownership did not have a great success and the 
economic crisis of the Depression is one popular explanation for this failure of policy.

Over the period, great shifts occurred in the relative rights of landlords and tenants - few would argue that the reduction in the exploitative powers of landlords was a bad thing but it was equally true that few regarded the law at the end of the period with equanimity. A conservative government was saved the philosophical dilemma of deciding on whether to accept the recommendations of its own investigator to introduce rent control by the outbreak of war. But there seems little doubt that the political pressures and the logic of its own position were forcing it in that direction.

In the broad sweep of events and actions there was something which seemed almost inexorable about the increasing degree of government intervention. Apart from the recidivist period of the mid twenties, both conservative and Labor Parties seemed to accept that increasing degrees of intervention in the market in the form of regulating individual dwellings, direct provision of dwellings and the application of town planning principles to whole urban areas, was the appropriate way to meet the demand for adequate housing. The creation of the New South Wales Housing Commission seemed to be the logical outcome of the evolution of policy and legislation. 


\section{Notes: Abbreviations}

NSWPD New South Wales Parliamentary Debates

NSWPP New South Wales Parliamentary Papers

PDP Premiers Department Papers (New South Wales Archives)

SMH Sydney Morning Herald

Lab Australian Labor Party, NSW Branch

Lib Liberal Party

Lib-Ref Liberal-Reform Party

Nat Nationalist Party

Prog Progressive Party

Pro Protectionist Party

Country Country Party

UAP United Australia Party

\section{Select Bibliography}

Anderson, A.W.(1935) 'The problem of the slums', Architecture, Vol. 1, December:286-87.

'Australians as Home Owners: Assistance Gained From Housing Schemes', (1926) Building, Vol 38, 12 April:52-63.

Bethune, G.(1977) Urban Home-Ownership in Australia: Some Aspects of Housing Demand and Policy', PhD thesis, Canberra, Australian National University.

Bland, F.A.(1938) 'Housing legislation-New South Wales', The Economic Record, Vol 14, June:78-82.

Boyce, F.B., Archdeacon.(1908) The Campaign for the Abolition of the Slums in Sydney, [Evidence before the Royal Commission into the Improvement of the City of Sydney, 1-29] 
Boyce, F.B., Archdeacon.(1934) Fourscore Years and Seven: the Memoirs of Archdeacon F.B. Boyce, a Clergyman of the Church of England of New South Wales, Sydney, Angus \& Robertson.

Briggs, P.J.(1972) Public Housing in Sydney: Past, Present and Future, PhD thesis, Sydney, University of NSW.

Castles, F. G.(1985) The Working Class and Welfare, Sydney, Allen and Unwin.

Church of England.(c.1912) What the Church of England Has Done for New South Wales, Sydney, W.M Andrews Printing Co.

Coghlan, T.A.(1969) Labour and Industry in Australia: from the First Settlement in 1788 to the Establishment of the Commonwealth in 1901 (reissue) Vol. 4, Hong Kong, Continental Printing. [first published 1918]

Daunton, M.J.(1988) Home loans versus council houses: the formation of American and British housing policy, 1900-1920 Housing Studies, Vol.3. No. $4,232-247$

De Baun, His Honour Mr Justice (1939) Increase of Rents, Report of the Industrial Commission of New South Wales to the Minister for Labour and Industry upon increases during the years 1937 and 1938 in the rents of Houses under $£ 3$ per week, leased or let as dwelling houses within the Metropolitan Area and Newcastle and Wollongong Districts [Legislative Assembly NSWPP, Vol 8. 1053 - 1136]

Dick, N.H.(1935) 'Housing and slum clearance in New South Wales', Australian Quarterly, Vol 7, No. 28, 81-85.

Evatt, H.V. (1920) 'A "Fair Rent" experiment in New South Wales'. Journal of the Society of Comparative Legislation and International Law, 3rd series, Vol 2: 10-20.

Fisher, S. F.(1981) 'An accumulation of misery', Labour History, Vol.40:16 28. 
Fisher, Shirley (1982) 'The pastoral interest and Sydney's public health', Historical Studies, Vol 20, No 78: 78-89.

Fitzgerald, J.D.(1909) 'The citizen and the slum', Australian Catholic Record, Vol 15, No 1, January: 25-39.

Fitzgerald, J.D.(1918) The Metropolitan Problems of Sydney. Sydney, W.A. Gullick, Govt Pr.

Fitzgerald, Shirley.(1987) Rising Damp:Sydney 1870-90, Melbourne, OUP.

Freeland, J.M. (1970) Architecture in Australia, Melbourne, Cheshire.

Freestone, R. (1989) Model Communities: The Garden City Movement in Australia, Melbourne, Nelson.

Gerathy, G.(1972) 'Sydney municipality in the 1880s', Royal Australian Historical Society: Journal, Vol 58, 23-54.

Gifford, J.K.(1947) Australian Banking, Brisbane, University of Queensland.

Glynn, S.(1970) Urbanization in Australian History 1788-1900, Melbourne, Nelson.

Griffiths, N.(1930) A History of the Government Savings Bank of New South Wales, Sydney, W.T. Baker \& Co. Ltd.

Hawker, G.N.(1971) The Parliament of New South Wales 1856-1965, Ultimo, NSW, Victor C.N. Blight, Govt Pr.

Herman, M.E.(1939) 'The Erskineville rehousing scheme', Art in Australia, 15 February, 68-71.

Housing Section: Homes for All'.(1926) Building, 12 Jan, 42-52.

Howard, E.(The Younger) (1919) 'Towns and industry', Science and Industry, Vol 1, No 2, 109-116. 
Irvine, Professor R.F. (1913) see NSW Commission of Inquiry into the Question of the Housing of Workmen in Europe and America.

Irvine, Professor R.F. (1914) Town Planning: What it Means and What it Demands, Sydney, Town Planning Association of NSW.

Jackson, R.V.(1970a) 'Owner-occupation of housing in Sydney: 1871-1891', Australian Economic History Review, Vol 10, No 2, 138-54.

Jackson, R.V.(1970b) Residential Building in Sydney, 1871-1900. PhD Thesis, University of Sydney.

Jackson, R.V. (1977) Economic Development in the Nineteenth Century, Canberra: ANU Press Publications.

Kass, Terry.(1987) 'Cheaper than rent: aspects of the growth of owneroccupation in Sydney 1911-66', in Max Kelly, (ed.) Sydney: City of Suburbs, Sydney, NSW University Press in assoc with the Sydney History Group, 77-94.

Kemeny, J.(1977) The ideology of home ownership', Arena, No.46, 81-89.

Loveday, P., Martin, A.W. and Parker, R.S.(eds) (1977) The Emergence of the Australian Political System, Sydney, Hale and Iremonger.

Manning, J. K. and Farquharson, D.(1947) The Law of the Banker and Customer in Australia, Sydney, The Law Book Co. of Australia.

Markey, Raymond (1988) The Making of the Labor Party in New South Wales 1880-1900. Kensington, NSW University Press.

Martin, A.W.(1980). Henry Parkes: A Biography, Melbourne, Melbourne University Press.

Mayne, A.J.C.(1980). 'City back-slums in the land of promise: some aspects of the 1876 report on overcrowding', Labour History, Vol 38, 26-39. 
Nairn, B. (1973) Civilising Capitalism: The Labor Movement in New South Wales 1870-1900, Canberra, ANU Press.

NSWPD (1905).Landlord Tenant Amendment Bill [Legislative Assembly, second reading].

New South Wales Commission of Inquiry into the Question of the Housing of Workmen in Europe and America (1913) .Report, Sydney, W.A. Gullick, Govt Pr.[The 'Irvine Report'].

New South Wales Legislative Assembly (1926) .Standard of Living-Living Wage: Determination of the Standard of Living and Declaration of the Livng Wage for Adult Male Employees. 15 December [Judgement of Industrial Commissioner A.B. Piddington, [NSWPP 1926-27].

New South Wales Legislative Assembly (1936). Report of the Director General of Public Health for the year 1935 [NSWPP 1936]

New South Wales Royal Commission of Inquiry on the Landlord and Tenant (Amendment )Act 1948 as amended (1961). 'Appendix 3: History of Rent Control in NSW'. [NSWPP Vol.4 1961-62].

O'Flanagan, N. (1988). 'John D. Fitzgerald and the town planning movement in Australia', Planning History, Vol 10, No 3, 4-6.

Parliament of the Commonwealth of Australia, Prices Investigation, No. 12 Report: Rents [Piddington Interstate Commission Inquiry]

Petition' (1937) .Erskineville, petition signed by 'Ratepayers and Residents of Erskineville, 23 August 1937, [Typescript.]

Piddington, A.B. (1918). see Parliament of the Commonwealth of Australia (1918)

Piddington, A.B.(1926). see New South Wales. Legislative Assembly.(1926). 
Pooley, C. G.(1989). 'Working class housing in European cities since 1850', in R. Lawton (ed.) The Rise and Fall of Great Cities, Bellhaven Press, London.

Sandercock, L.(1975) Cities for Sale: Property, Politics and Urban Planning in Australia, Melbourne, Melbourne Univesity Press.

Spearritt, P.(1973) 'The Australian slum stigma, Australia and New Zealand Journal of Sociology, June, 32-36.

Spearritt, P.(1974) 'Sydney's slums: middle class reformers and the Labor response', Labor History, No.26, 65-81.

Sulman, John (1914) Co-partnership Housing. Sydney, Town Planning Association of NSW.[No3]

The Housing Board of N.S.W. 1912-1924 [Typescript]

Troy, P.N.(1988) 'Government housing policy in New South Wales 17881900', Housing Studies, Vol 3, No 1, 20-30.

Volke, H.(c.1980) "I couldn't put a deposit on a knob of blue": A Study of the Erskineville Housing Project, Unpublished MA thesis, Macquarie University.

Watson, J.H.(1921) 'Matraville', [Collected clippings held in Mitchell Library]

Wilkinson, Professor L.(1921) 'Domestic architecture', Building, 12 Sept:6269. 


\section{APPENDIX 1: NSW HOUSING AND RELATED LEGISLATION, 19th Century}

$\begin{array}{lll}\text { NSWPD } & \text { 1890:166 } & \text { Homes Preservation Bill } \\ 1890: 357 & \text { Lodgers Protection Bill } \\ 1893: 1122 & \text { Adjournment Debate: The Unemployed } \\ 1893: 5557 & \text { Distress for Rent Abolition Bill } \\ 1893: 7838 & \text { Crown Land Settlements Bill } \\ 1893: 8215 & \begin{array}{l}\text { Crown Land Settlements Bill also the } \\ \text { Labour Settlements Bill }\end{array} \\ 1893: 1087 & \text { Adjournment Debate: The Unemployed } \\ 1894: 1952 & \text { Distress for Rent Abolition Bill } \\ 1894: 3118 & \text { Labour Settlements Act Amendment } \\ & \text { Bill } \\ 1896: 3559 & \text { Homes Protection Bill } \\ 1898: 325 & \text { Distress for Rent Restriction Bill }\end{array}$

NSW STATUTES

$\begin{array}{ll}1879 & \text { City of Sydney Improvement Act, No.25 } \\ 1880 & \text { Electoral Act, No.44 } \\ 1893 & \text { Labour Settlements Act, No.34 } \\ 1893 & \text { Parliamentary Electorates and Elections Act No.38 } \\ 1895 & \text { Public Service Act, No.25 } \\ 1896 & \text { Factories and Shops Act, No.37 } \\ 1896 & \text { Public Health Act , No.38 }\end{array}$




\section{APPENDIX 2: NSW HOUSING: SIGNIFICANT \\ EVENTS \& RELATED \\ LEGISLATION, 1900-1941}

\begin{tabular}{|c|c|c|}
\hline Government & Year & Title \\
\hline Pro & 1900 & Sydney Corporation (Amendment) Act \\
\hline Pro & 1901 & $\begin{array}{l}\text { Blockholders Act } \\
\text { Closer Settlement Act } \\
\text { Shearers' Accommodation Act } \\
\text { Sydney Harbour Trust Act }\end{array}$ \\
\hline Pro & 1902 & $\begin{array}{l}\text { Public Health Act } \\
\text { Sydney Corporation Act }\end{array}$ \\
\hline
\end{tabular}

Pro/Lib-Ref $1904 \quad$ Housing of the Working Classes Bill initiated by E.W. O'Sullivan in NSW Parliament but not brought in.

Lib-Ref

1905 Sydney Corporation Amendment Act

[Provision '... to give said Council power to purchase or resume lands ... and to provide for workmen's dwellings']

Lib-Ref

1906 Local Government Act

Government Savings Bank Act

Lib-Ref

1907

Lib-Ref

1908

NSW Royal Commission of Inquiry into the Improvement of the City of Sydney appointed. [Report published in 1909].

Lib-Ref 1909

Lib-Ref/Lab

1910

$\mathrm{Lab}$

1911 NSW Select Committee on Increase in House Rents appointed. [Progress report and final report published in 1912]. 
1912 Housing Act [Established Housing Board to provide public rental housing].

Sydney Corporation (Dwelling Houses) Act

Dacey Gardens suburb commenced by Housing Board.

Haberfield Garden Suburb commenced.

NSW Commission of Inquiry into the Question of the Housing of Workmen in Europe and America appointed. ['Irvine' Report published in 1913].

Lab

1913 Government Savings Bank Amendment Act

Fair Rents Bill

Town Planning Association founded.

$\mathrm{Lab}$

1914 Daceyville Extension Act

$\mathrm{Lab}$

$1915 \quad$ Fair Rents Act

$\mathrm{Lab} / \mathrm{Nat}$

1916 Rural Tenants Improvements Act

Nat

1917 Voluntary Workers (Soldiers Holdings) Act

[Facilitated an enlarged program by the Voluntary

Workers' Association to erect houses for soldiers,

especially at Matraville].

Matraville garden suburb commenced.

Nat

1918 Piddington Inter-State Commission inquiry house rents.

Commonwealth War Service Homes Act [Daceyville

Extension 2 facilitated under this scheme]

Nat

1919 Housing (Extension) Act

Local Government Act

$\mathrm{Nat} / \mathrm{Lab}$

1920 Fair Rents (Amendment) Act

NSW Select Committee on the Slum \& Congested Areas,

Sydney and Newcastle. [Progress report published in 1920; no final report appeared].

Government Savings Bank (Rural Bank) Act 
Lab

1921

$\mathrm{Lab} / \mathrm{Nat}$

1922

NatProg

1923

Co-operation Act

Government Savings Bank (Amendment) Act

NatProg

1924

Housing (Amendment) Act [Dissolved Housing Board and public rental housing abandoned until 1930s]

City of Sydney Improvement (Amendment) Act

NatProg/Lab

1925

Lab

1926

Fair Rent (Amendment) Act

$\mathrm{Lab} / \mathrm{Na}$

1927

Nat-Country

Nat-Country

$\mathrm{Nat} / \mathrm{Lab}$

1930

$\mathrm{Lab}$

193

Lab/UAP

1932

Landlord and Tenant (Amendment)

Sydney Corporation Act 1932-34

Building Relief Agency established [Functioned until about 1942].

UAP-Country 1933 
UAP-Country

1934

UAP-Country

1935

UAP-Country

UAP-Country

UAP-Country

1938

UAP-Country

UAP-Country

$\mathrm{UAP} / \mathrm{Lab}$

Housing of the Unemployed Act 1914-37 [Established the Homes for the Unemployed Trust which

functioned until 1946].

City of Sydney Improvement (Amendment) Act

Housing of the Unemployed (Grant) Act

Town and Country Planning Institute founded.

Home Building Scheme Agency established.

Landlord and Tenant (Amendment) Act

Provisional Committee for Slum Clearance established by the NSW government.

1936 Housing Improvement Act [Established the Housing Improvement Board]

Housing of the Unemployed (Amendment) Act

Landlord and Tenant (Amendment) Act

NSW Housing Conditions Investigation Commission

appointed. [Report published in 1937].

Australia: Royal Commission on Banking Report

Housing (Further Provisions) Act [Empowered

Housing Improvement Board to undertake

Erskineville work].

Fair Rents Act [Removed from Statute Book]

Landlord and Tenant (Amendment) Act

Erskineville Rehousing Scheme commenced by Housing Improvement Board

$1939 \quad$ Fair Rents Act [

1940 Local Government Regulation of Flats Act

1941 Housing Act [[Established NSW Housing Commission] Landlord and Tenant (Amendment) Act 


\section{URP Working Papers}

$1987-1990$

No 1. Walker, Jill. Home-based Working in Australia: Issues \& Evidence. October 1987. [Out of Print]

No 2. Neilson, Lyndsay R. Metropolitan Planning in Australia: The Instruments of Planning - Regulation. April 1988. [Out of Print]

No 3. Neutze, Max. A Tale of Two Cities: Public Land Ownership in Canberra and Stockholm. May 1988. [Out of Print]

No 4. Troy, P. N. and C.J. Lloyd. 'Simply Washed Out by a Woman': Social Control, Status and Discrimination in a Statutory Authority. June 1988. [Out of Print]

No 5. Wilmoth, David. Sydney's Metropolitan Strategy with A Comment by James R. Conner. June 1988. [Out of Print]

No 6. Metropolitan Planning in Australia: Urban Management. August 1988. [Papers by: M. Neutze, 'Planning as Urban Management: A Critical Assessment' and J. Mant, 'The Instruments of Planning: Urban Management'.] [Out of Print]

No 7. Self, Peter. Metropolitan Planning: An International Perspective. September 1988. [Out of Print]

No 8. Troy, P. N. and C.J. Lloyd. Industrial Organisation: Work Practices and Rituals in the Hunter District Water Board. December 1988. [Out of Print]

No 9. Howard, Michael. Advocacy and Resistance: The Question of a Post-War Commonwealth Government Role in Community Facilities, Town Planning and Regional Planning, 1939-52. December 1988. [Out of Print]

No 10. Badcock, Blair. Metropolitan Planning in South Australia. January 1989. [Out of Print]

No 11. Metropolitan Planning in Australia: Urban Consolidation. May 1989. [Papers by:

R. Cardew, 'Urban Consolidation: A Comment on Prospects \& Policy'; P.N. Troy, 'Metropolitan Planning \& Urban Consolidation'; and R. Bunker, 'A Decade of Urban Consolidation'].

No 12. Bourassa, Steven. Postmodernism in Architecture and Planning: What Kind of Style? May 1989. [Out of Print]

No 13. Bourassa, Steven. Land Value Taxation and Housing Development for Three Cities in Pennsylvania. June 1989.

No 14. Parkin, Andrew. Metropolitan Planning and Social Justice Strategies. August 1989. [Out of Print]

No 15. Sawer, Marian. The Battle for the Family: Family Policy in Australian Electoral Politics in the 1980s. August 1989. [Out of Print] 
No 16. Neutze, Max and Kendig, Hal. Achievement of Home Ownership among Post-War Australian Cohorts. September 1989.

No 17. Dawkins, Jeremy. The Planning of Places Like Perth. October 1989.

No 18. O'Flanagan, Neil. The Sydney Harbour Trust: the Early Years. November 1989.

No 19. Smith, Susan J. Gender Differences in the Attainment and Experience of Owner Occupation in Australia. December 1989.

No 20. Sanders, Will. Policy-Making for Sydney's Airport Needs: A Comparative and Historical Perspective. December 1989.

No 21. Government Provision of Social Services Through Nonprofit Organisations. February 1990. [Papers by Michael Lipsky, 'A Note on Contracting as a Regime, and its Possible Relevance to Australia' and Michael Lipsky and Steven Rathgeb Smith, 'Government Provision of Social Services Through Nonprofit Organisations'].

No 22. Self, Peter. Metropolitan Planning: Economic Rationalism and Social Objectives. July 1990.

No.23 Greig, Alastair. Retailing is More Than Shopkeeping: Manufacturing Interlinkages and Technological Change in the Australian Clothing Industry. August 1990.

No.24 Troy, Patrick.The Evolution of Government Housing Policy: The case of New South Wales 1901 -1941. September 1990

All URP Working Papers are free of charge (unless otherwise noted) and available from The Secretary, URP, RSSS, Australian National University, GPO Box 4, Canberra, ACT 2601 
